\title{
Assessing Cross-National Invariance of the Three-Component Model of Organizational Commitment: A Cross-Country Study of University Faculty
}

\author{
Shefali Nandan, $\mathrm{PhD}$ (University of Allahabad, India) \\ Daphne Halkias, $\mathrm{PhD}$ (International School of Management, France) \\ Paul W. Thurman, Prof. (Columbia University, USA) \\ Marcos Komodromos, $\mathrm{PhD}$ (University of Nicosia, Cyprus) \\ Alserhan Baker Ahmad PhD., (Princess Sumaya University for Technology, Jordan) \\ with \\ Chris Adendorff, PhD (Nelson Mandela Metropolitan University, South Africa) \\ Norashfah Hanim Yaakop Yahaya Al-Haj, PhD (Teguh SNR Mgmt Consulting, Malaysia) \\ Alfredo De Massis, PhD (University of Bergamo, Italy) \\ Eleanna Galanaki, $\mathrm{PhD}$ (Athens University of Economics and Business, Greece) \\ Stuart Graham, Prof. (Queen Margaret University, Scotland) \\ Norma Juma, $\mathrm{PhD}$ (Washburn University, USA) \\ Eileen Kwesiga, PhD (Bryant University, USA) \\ Anayo D. Nkamnebe, PhD (Nnamdi Azikiwe University, Nigeria) \\ Claire Seaman, Prof. (Queen Margaret University, Scotland) \\ Janine Zacca, PhD (Lebanese American University, Lebanon)
}

\begin{abstract}
Purpose: This study examines affective commitment, normative commitment, and continuance commitment in a cross-national context to identify if the effect of country-specific cultural orientation on organizational commitment of faculty in higher education functions invariably in different countries.

Methodology: The work expands on Meyer and Allen's (1991) three-component model of organizational commitment. It includes a review of relevant literature on 10 countries and the results of a survey of university faculty members in 8 of these countries, assessing their institutions' human resources practices and their effect on organizational commitment. Findings: Though certain differences may exist between different countries and cultures with respect to the three-component model of organizational commitment, there is strong evidence of the existence of invariance and thus generalizability of the model across cultures.

Research: Cultural studies have focused on differences in organizational commitment at national levels. Further attempts to identify the universality of factors leading to organizational commitment should account for culture in the study of employee-related globalization issues in higher education institutes. Knowledge of cultural impact is also useful from a managerial perspective, and for the design of relevant strategies.

Practical Implications: National context plays a major role in shaping the nature of educational institutions. This study brings out the need for a deeper understanding of invariance in organizational commitment (inter alia, through the three-component model).

Originality/Value: This study contributes to a better understanding of the relationship between organizational commitment and its various antecedents, including human resources management practices, for faculty in higher education institutes.
\end{abstract}




\section{Introduction}

The drivers of change in higher education today include technology, changing demographics, economy (Futhey, Luce, \& Smith, 2010; Goldstein, 2006), globalization of economic, cultural, and political institutions, increasing interdependence of nations (Morey, 2004), and revolution in information and communication technology (Swist, \& Kuswara, 2016). The changes have not only necessitated adoption of new teaching approaches in educational institutions, they have also resulted in a change in work culture and management styles in universities. The challenges are similar to that of business organizations - there has been not only an increase in pressure for accountability in resource usage from both internal and external bodies in higher education institutions (Hawkins, 2008) these institutions are now also required to adopt efficiency, responsiveness, and innovation in their approach (Charlier, \& Croché, 2016). Thus, faculty in these institutions are faced with new expectations and a different work environment, to which they must adapt themselves. In the changing socio-economic scenario, several models have been recommended to redesign institutions. These include the entrepreneurial model (Wissema, 2008; Etzkowitz, 2008) and the 'new managerialism' (Deem, 1998, 2001) model, among others. Managerialism is characterized by many highly formal organizational processes and systems, high accountability and standards, quick decision making, competitiveness, responsiveness and adaptability, and excellence (Kauffmann Foundation, 2008).

Though different universities have varying focus (Pratt, 2001; Jacob, Lundqvist, \& Hellsmark, 2003) and may view 'excellence' differently (Tasopoulou et al., 2017; van Vught, 2008) at a national level, however, factors like traditions, hierarchies, and pressure groups (Bourdieu, 1999) play a major role in shaping the nature of higher education institutions. Thus, universities in different countries are expected to have a different work environment. Despite these local and national differences, educational institutions in general have a unique culture that provides an environment for independent thinking, autonomy, participation, and shared governance (Allen \& Fifield, 1999; Rowley \& Sherman, 2001). Certain academics in every educational institution, are always seeking knowledge, from varied sources (Bird \& Allen, 1989). Stiles (2004) proposed three types of academic identities — separatist, integrationist and hegemonist - that represent different sets of academic organization with separate institutional strategies, and further stated that when the values of academics did not correspond with the values of their 'academic organization', there arise problems.

In the networked and globalized world, universities today, like business organizations, have culturally diverse faculty members (Unum, 2013). In view of the varied challenges faced by the human resources departments in institutions of higher education, these organizations must have committed employees who can adapt to change and deliver results (Razali \& Vrontis, 2010). Against this background it is important to study organizational commitment of faculty in higher education. Since changes are taking place globally, so it becomes imperative to understand the phenomenon of organizational commitment across cultures. Meyer and Allen (1991) proposed organizational commitment as being made up of three components: affective commitment, normative commitment, and continuance commitment.

The purpose of this study is to examine the invariance of affective commitment, normative commitment, and continuance commitment in a cross-national context and to identify if the effect of country-specific cultural orientation on organizational commitment of faculty in higher education functions invariably in different countries. The study attempts to identify the universality of factors leading to organizational commitment. The research question to meet the 
goals of this study was: Is there a relationship between organizational commitment and its various antecedents for faculty in higher education? Following, the hypothesis central to this study extends Meyer and Allen's (1991) main thesis and their suggestion "that a complementary set of processes may be involved in the commitment-behavior link" (1991, p. 62).

\section{Theoretical Framework}

Porter, Steers, Mowday, and Boulian (1974) defined organizational commitment as the strength of an individual's identification with and involvement in an organization. It is important to understand what leads to organizational commitment as it is related to two very important variables: the intention to leave an organization and actual withdrawal behavior (Allen \& Meyer, 1996). Employee expectations of both intrinsic and extrinsic growth affect their commitment towards an organization. Thus, it has been shown that personal development opportunities (Liu \& Wang, 2001), promotion and training (Long, Fang, \& Ling, 2002), and learning opportunities (Bashir \& Long, 2015; Ng, Butts, Vandenberg, DeJoy, \& Wilson, 2006) affect organizational commitment. Such researchers suggest that personal and professional growth affect psychological attachment to employer (Weng, McElroy, Morrow, \& Liu, 2010).

Meyer and Allen's (1991) three-component model of commitment explains that commitment to an organization is a psychological state and has three distinct elements: (1) affective commitment (emotional attachment to job), (2) continuance commitment (fear of loss), and (3) normative commitment (sense of obligation to stay).

According to Allen and Meyer (1990), experiences in the organization that "fulfil employees' needs to feel comfortable within the organization and competent in the work role" (p. 4) develop affective commitment. Continuance commitment is mainly dependent on the investment that an employee has made in the organization (e.g., contribution to pension funds and other such major investments) and the perceived lack of alternative employment

opportunities. Normative commitment is based more on early experiences of socialization and on the sense of obligation to stay (Allen \& Meyer, 1996) as an organization might suffer due to the leaving of an employee.

Meyer, Stanley, Herscovitch, and Topolnytsky (2002) identified that all three forms of commitment are related negatively to withdrawal behavior and turnover. Affective commitment had the strongest and most positive correlations with favorable behaviors like attendance, performance, and organizational citizenship behavior. Normative commitment had somewhat lesser correlation with desirable outcomes, while continuance commitment was either unrelated or negatively related to such outcomes.

Most cultural studies have focused on the differences in organizational commitment at national levels. This theoretical framework provides the knowledge base for the design of the study, which study proposes to expand the existing theory by studying invariance in affective commitment, normative commitment, and continuance commitment in the faculty of universities in at least eight countries, and expand the three-component model of organizational commitment in a cross-national context. Theories that are considered universal and that are based upon assumption of similarity in behaviors of employees in different cultures are vulnerable to being 'partially applicable' or 'not applicable at all' in many countries. If culture is found to have an important impact upon the three-component model of organizational commitment, it should occupy an important place while studying employee-related globalization issues in institutes of higher education. The knowledge of cultural impact is also useful from a managerial perspective, while designing strategies. 


\section{Literature Review}

Commitment is one of the most widely studied phenomena in organizations. It is important to have committed employees, as employees with higher commitment perform better than those having lesser commitment (Mowday, Porter, \& Dublin, 1974). Moreover, commitment may also be seen as an indicator of organizational effectiveness (Schein, 1970; Steers, 1975). Commitment has been found to be negatively related to turnover (Cooper-Hakim \& Viswesvaran, 2005; Robertson Cooper \& Bank Workers Charity, 2017), absenteeism (Farrell \& Stamm, 1988), and counterproductive behavior (Dalal, 2005), while it is positively related to job satisfaction (Cooper-Hakim \& Viswesvaran, 2005), motivation (Mathieu \& Zajac, 1990), and organizational citizenship behaviors (Riketta, 2002). It has been found that a positive relationship exists between commitment and certain values and beliefs of employees in an organization (McCaul, Hinsz, \& McCaul, 1995; Mueller, Wallace, \& Price, 1992). In this regard, research by Robertson Cooper and Bank Workers Charity (2017) emphasizes the benefits of organizations shifting focus from work-life balance to work-life integration in recognition of the challenges of contemporary demands on work and life equally. Thus, organizational culture, management style, etc. affect commitment (Al-Sada, Al-Esmael, \& Faisal, 2017; Yahaya \& Ebrahim, 2016).

There are various employee-related factors that affect organizational commitment. Steers (1977) found that besides job characteristics, personal characteristics and work experience also influence commitment. Commitment has been positively related to personal characteristics such as age (Mathieu \& Zajac, 1990) and duration of service in a particular organization (Luthans, McCaul, \& Dodd, 1985; Kushman, 1992; Mathieu \& Zajac, 1990). With respect to continuance commitment, age proved to be negatively related (Bayona-Sáez, Goñi-Legaz, \& MadorránGarcía, 2009). An employee's beliefs about organizational support (Eisenberger, Fasolo, \& Davis-LaMastro, 1990), fair treatment (McFarlin \& Sweeny, 1992), equity in pay workload (Quirin, Donnelly, \& O'Bryan, 2001), and enhancement of the feeling of personal competence and self-worth (Mathieu \& Zajac, 1990; Steers, 1977) have been found to be strongly linked with organizational commitment. Employee perceptions of human resource management (HRM) practices also have an impact on organizational commitment (Steijn \& Leisin, 2006).

There is evidence of organizational factors also affecting organizational commitment (Ayari-Gharbi, Besson, \& Mamlouk, 2014). The presence of certain work characteristics like autonomy (Dunham, Grube, \& Castaneda, 1994) and job challenge (Meyer, Irving, \& Allen, 1998) might strengthen perceptions of personal competence, which is likely to lead to increased commitment (Mathieu \& Zajac, 1990; Steers, 1977). Even promotion (Gaertner \& Nollen, 1989), high compensation (McElroy, 2001), and opportunities for social interaction (Steers, 1977) lead to feelings of commitment. Other factors that research studies have found to be positively related to organizational commitment are job security (Yousef, 1998) and general working conditions (Painter \& Akroyd, 1998; Richards, O’Brien, \& Akroyd, 1994).

Different studies indicate that both differences and similarities exist at cross-national level with respect to different aspects of affective commitment, normative commitment, and continuance commitment. For example, in a six European country study no difference was noted in affective commitment and continuance commitment in the sample, but substantial crossnational differences were found for normative commitment (Eisinga, Telkeen, \& Dooreward, 2010). Personal variables and group variables such as working atmosphere have been found to have a positive impact on affective commitment, while job-related characteristics did not appear to be significant in a study of Spanish academic staff at a university (Bayona-Sáez, Goñi-Legaz, 
\& Madorrán-García, 2009). However, a study of Dutch public sector employees revealed a relatively major importance of job and organizational characteristics and the relatively minor importance of personal characteristics for affective commitment (Steijn \& Leisin, 2006). In Pakistani university teachers distributive justice was more significantly related to organizational commitment than procedural justice (Chughtai \& Zafar, 2006), while research studies in the United States (US) have revealed that procedural justice is a stronger predictor of organizational commitment whereas distributive justice is more strongly related to personal outcomes such as pay satisfaction (e.g., Folger \& Konovsky, 1989). Commitment experienced by the faculty member was associated with the fit between the task, goal, or purpose of the job and the personal values of individuals in the US and Canada (Henkin \& Marchiori, 2003).

An equally important distinction to take into consideration is the difference between national culture and culture of the international university in that country. In this regard, AyariGharbi et al. (2014) suggest that a higher education institution's external environment (international academic market, host country culture, and expatriate teachers' personal characteristics) has an influence on teachers' organizational commitment. It also follows then that a well-established university will differ from a 'younger' educational institution in that the former will likely have over time embraced elements of its host culture and better understand the demands of work and life in the country, and so this too plays a role in teachers' commitment.

The bulk of the research and literature on organizational commitment has been company specific or nation specific, or focused on variance between countries. Therefore, in the era of globalization, an examination of international dynamics in terms of invariance is useful and timely for both contemporary research and practice (Vrontis \& Thrassou, 2007).

\section{Cross-National Literature Review}

Greece. Greece is represented in most major studies of cross-cultural variation (Hofstede, 2001; House, Hanges, Javidan, \& Dorfman, 2004; Papalexandris, 2007; Papalexandris, Halikias, \& Panayotopoulou, 2002). Greek researchers have also focused their attention on organizational commitment at large quite early. This has resulted in a substantial volume of empirical evidence on organizational commitment from Greece, given the relatively small size and limited importance of this country, globally. So, despite the assertion of recent writings that organizational commitment has been rarely reported from a Greek perspective (Markovits, Davis, \& van Dick, 2007; Dimitriades \& Papalexandris, 2012), it appears that there is a considerable body of evidence on organizational commitment from this country. The - mostly Greek - researchers who have dealt with organizational commitment in Greece come from diverse disciplines and therefore have followed different approaches and methodologies on the study of organizational commitment, and they have also focused on different aspects of the topic.

Organizational commitment has attracted the interest of Greek management scholars early on, so there are numerous studies focusing on organizational commitment at large (Bourantas \& Papalexandris, 1992), but also in relation to personality (Bourantas \& Papalexandris, 1999), job satisfaction (Markovits, Davis, \& van Dick, 2007), employee performance (Dimitriades \& Papalexandris, 2012), organizational culture (Simosi \& Xenikou, 2010), communication (Simosi, 2010; Vakola \& Bouradas, 2005), and leadership styles (Bourantas, 1988; Epitropaki, 2003; Epitropaki \& Martin, 2005; Martin, Thomas, Charles, Epitropaki, \& McNamara., 2005). The effect of specific HRM practices (Panagiotakopoulos, 2011; Katsikea, Theodosiou, Perdikis, \& Kehagias, 2011; Nikandrou, Panayotopoulou, \& Apospori, 2008) and functions (Simosi, 2010; Katou \& Budhwar, 2008; Sahinidis \& Bouris, 2008) on organizational commitment has also been repeatedly studied, while the effect of 
specific critical organizational events, such as mergers and acquisitions (Bourantas \& Nicandrou, 1998) and change management (Tomprou, Nikolaou, \& Vakola, 2012; Vakola \& Nikolaou, 2005), on commitment has also been studied in the Greek context.

At the same time, research on organizational commitment has focused on different sectors of the economy, as well as on different management functions. There have been studies focusing mainly on the public or private sector (Markovits, Davis, \& van Dick, 2007), on banks (Dimitriades, 2011), on hotels (Glinia, Costa, Mavromatis, Tsitskari, \& Kalaitzidis, 2004), and on smaller firms (Panagiotakopoulos, 2011). There have also been studies focusing on a specific work category/profession, most notably front-line personnel (Bozionelos \& Kiamou, 2008) (such as salespeople (Stathakopoulos, 1996; Theodosiou \& Katsikea, 2007; Panagopoulos \& Dimitriadis, 2009), retailers (Giannikis \& Mihail, 2008), and hotel employees (Glinia, Costa, Mavromatis, Tsitskari, \& Kalaitzidis, 2004)) who come into contact with customers. What is actually missing in the Greek literature on organizational commitment are international studies that would allow for comparisons with the experience from other countries. The gap in the Greek literature on organizational commitment is the lack of empirical evidence that would transcend Greek borders.

Italy. Studies on organizational commitment in Italy focus on Italian employment in the public and private sectors; but to our best knowledge, no studies analyze the topic among universities employees. A number of scholars have chosen Italy within a list of countries to account for cultural context as a variable affecting organizational commitment (Brescani, Thrassou, \& Vrontis, 2012) Thus, for example, Italian nurses' mean score for continuance commitment was the highest with respect to Hungary, the United Kingdom (UK), and the US, and values were found to be significantly correlated with continuance commitment; moreover, openness to change values and self-enhancement values were negatively correlated with affective commitment, whereas conservation values had a significant and positive correlation with affective commitment (Glazer, Daniel, \& Short, 2004).

Compared with Belgium, the Netherlands, and Sweden, in Italy subjective job insecurity was found to be negatively associated with organizational commitment (De Witte \& Näswall, 2003). Finally, one study focused on the Italian labor market situation after the reforms (introduced in the 1990s) that introduced flexible arrangements and atypical work contracts (Gianecchini, Imperatori, Grandori, \& Costa, 2008). It deals with normative commitment as regards the legislative framework that affects firms and individuals when choosing and managing employment contracts.

India. The liberalization and bold economic reforms initiated by the government of India in the early 1990s, coupled with advancements in information technology (IT), have affected the organizations and workforce in many ways. A shift is taking place in the pattern of HRM practices in Indian organizations from traditional administrative type to a more strategic and proactive type (Balasubramanian, 1995; Budhwar, 2009) that should manage change and be an employee champion (Srimannarayana, 2010).

Like in many other sectors, there has been an impressive growth in higher education in India in terms of increase in number of institutions/universities and enrollments (UGC Annual Report, various years). Just as in any other industry, HR practices seem to be important in educational institutions as well. Bhatnagar (2008) found a positive relationship between strategic HR roles and organizational commitment. It has been found that teachers' job satisfaction is a multifaceted phenomenon (Sharma \& Jyothi, 2006) that is critical to commitment (Mathieu \& Zajac, 1990). 
There are very few studies available on organizational commitment in university employees in the Indian context. Higher education institutes may be viewed as service-providing organizations. Findings in other service sector industries in India may be an indication towards those in institutes of higher education. In service sector organizations excessive behavior controls may adversely affect work performance. The type of activity requires the application of knowledge, intellectual skills, and strong internal motivation (Nigam, 2008). A case study of an Indian university showed that HR practices include creating a vision, linkages with agencies, training, resource generation, restructuring of curricula, decentralization of administration, and support to the disadvantaged sections. Direct and positive correlation was found between leadership behavior of heads of department and efficacy of employees in the Indian university (Tabbodi \& Prahallada, 2009).

HRM practice can contribute significantly to organizational commitment, and performance appraisal has emerged as a significant predictor of organizational commitment in consultancy and research-based organizations (Shahnawaz \& Juyal, 2006). Employee-friendly work environment, career development, development-oriented appraisal, and comprehensive training show a significant positive relationship with organizational commitment in India (Paul \& Anantharaman, 2004). Bakhshi, Kumar, and Rani (2009) reported a positive relationship between distributive and procedural justice with organizational commitment of medical college employees in India.

Bhatnagar (2005) identified a need to move from control-oriented to commitmentoriented work practices and to align configurational HR strategies to these high-commitment work practices.

To foster organizational commitment, managers need to create an environment where employees can feel a sense of control over resources and decision making (Rama-Krishna, n.d.). Psychological empowerment was found to influence affective and normative commitment positively in IT professionals in India (Jha, 2011). Bhatnagar (2008) proposed that psychological empowerment facilitates organizational learning capabilities, leading to higher commitment.

Personal variables like age and tenure have been reported to have an impact on affective, continuance, and normative commitment at each career stage in India (Kaur \& Sandhu, 2010). Kumar \& Bakshi (2010) reported that the personality type of an employee has an impact on all the three forms of organizational commitment.

Lebanon. Lebanon is a Middle Eastern country that is unique among other Arab countries as to the freedom of education and work with no discrimination regarding religion, race, and gender. Nevertheless, Lebanese society is affected by its Arab environment and its religious and cultural factors, which drew researchers to focus on gender issues in the workplace, with limited research on job satisfaction and organizational commitment mainly applied to the Lebanese banking sector.

Crossman \& Abou-Zaki (2003) found that job satisfaction is not related to an individual facet, and that satisfaction with one job facet might lead to satisfaction with another in commercial banks. On the other hand, Dirani (2009), in a study of employees of Lebanese commercial banks found a relationship between learning organization culture, employee job satisfaction, and organizational commitment. Dirani (2009) specified that dimensions like creating continuous learning and team learning are not significant predictors of organizational commitment, while dimensions like system connectedness, providing leadership, promoting inquiry and dialogue, and shared systems were significant predictor variables. Ballout (2009) found that career commitment was positively related to objective career success (salary level) 
and subjective career success (career satisfaction) among employees with moderate to high selfefficacy.

In a study of the retail sector in Lebanon, Messarra and Karkoulian (2008) found that affective organizational commitment increased after a war crisis as compared to before the war crisis, continuance commitment decreased, and normative commitment increased, with no change in overall organizational commitment. In a similar study conducted in medium-size organizations in Lebanon, using the three-component model of Meyer and Allen (1997), Nasr (2010) reported that workplace stress is negatively correlated with affective commitment, positively slightly correlated with continuance commitment, and slightly positively correlated with normative commitment. Nasr (2010) added that career path is negatively related to normative commitment, is not correlated to affective commitment, and is not correlated to continuance commitment.

Malaysia. The Ministry of Higher Education in Malaysia is a government ministry that is responsible for determining the policies and direction of higher education in the country. Development of the higher education sector is being seen as a prerequisite to strong economic growth by the Government of Malaysia, articulating the effort to establish a world-class university system, to make the country a regional education hub, and to transform Malaysia into a knowledge-based economy (Ministry of Education, 2004).

Rosdi and Harris (2011) and Rahman and Hanafiah (2002) found that professional commitment was best related to organizational normative commitment and least linked to organizational continuance commitment. A more recent case study by Bashir and Long (2015) appears to corroborate these findings. Their survey of academic staff at a university in Malaysia found a significant and positive relationship between affective and normative commitment components of organizational commitment and variables related to training (availability, motivation, support by co-workers and supervisors, and benefits). The results however returned a non-significant relationship with continuance commitment.

Karim and Noor (2006), in a study on the academic librarian sector in Malaysia, found that employees who have strong affective commitment are more likely to remain in the organization because they want to, and will continue to work for the organization, when they agree with the organization's goals. Meanwhile, the study of Rahman and Hanafiah (2002) showed that while a normative-orientated measure of professional commitment was strongest in the prediction of organizational normative commitment, an affectively inclined measure of professional commitment associated highly with organizational affective commitment. Besides, an employee with high continuance commitment is more likely to remain in the organization.

Nigeria. Emerging studies on organizational commitment in Nigeria have linked demographic, personal, psychological, organizational, and other variables as predictors of worker commitment. For instance, Tella, Ayeni, and Popoola (2007) investigated the nexus between motivation, job satisfaction, and organizational commitment among library personnel and reported a positive correlation between work motivation and job satisfaction and a negative correlation between motivation and organizational commitment. The study reported that tenure has no relationship with organizational commitment. In another study, job satisfaction and organizational justice were identified as potent predictors of organizational commitment (Gbadamosi \& Nwosu, 2011) among staff of a private university in Nigeria.

In a study on medical records personnel in university teaching hospitals in Nigeria, Igbeneghu and Popoola (2011) found that locus of control has a significant inverse relationship with organizational commitment, that job satisfaction has a significant positive relationship with 
organizational commitment, and that the combination of work locus of control and job satisfaction could significantly influence organizational commitment.

Salami (2008) reported that emotional intelligence, work-role salience, achievement motivation, job satisfaction, and all demographic factors except gender significantly predicted organizational commitment of the workers in Nigeria. Adeyemo (2000) reported a positive correlation between education and organizational commitment. A partial relationship exists between demographic factors and organizational commitment (Akintayo, 2005). In another study, 'altruistic love' as an element of 'workplace spirituality' was found to foster a high level of workers' affective and normative commitment and low workers' continuance commitment (Ahiauzu \& Asawo, 2009). Balogun, Oladipo, and Odekunle (2010), in a study of organizational commitment among bank employees, showed that job esteem is an established factor that can influence organizational commitment, and that job status did not have significant influence on organizational commitment. Other studies (e.g., Popoola, 2009, 2007, 2006; Oladele, 2005; Opayemi, 2004; Taiwo, 2003) have equally identified many predictors of correlates of organizational commitment among Nigerian workers.

Russia. Organizational commitment theory as a separate field of study has not gained much interest among Russian scholars yet. Some papers reveal a new subject and study field for Russian business schools classified as 'organizational commitment theories' that was developed in the US. Buchko, Weinzimmer, and Sergeyev (1997) examined whether US-based organizational commitment theories are applicable in Russian organizations and found that job involvement, job satisfaction, and organizational commitment of Russian workers is relative to US workers and data. These results indicate a positive relationship between US-based correlates of organizational commitment in a Russian context. A later study found out that US-based theories on antecedents, correlates, and consequences of organizational commitment are generally applicable for Russian workers (Buchko, Weinzimmer, \& Sergeyev, 1998). Crosscultural research that tests US-based theories about organizational commitment was used in Ukrainian and Russian contexts later in 2011. 'Soviet' and 'post-Soviet' leadership were known as strict, controlling, and stubborn (Buchko, Weinzimmer, \& Sergeyev, 1998). Lack of integrity was identified as a reason of post-Soviet managing system failures (Longenecker, 2001).

Scotland. Organizational commitment amongst university faculty is an area that has received some attention in the international research literature, but where more primary and focused research in the Scottish and broader UK context is needed. A review of the theoretical basis for research in this area (Ramiall, 2004) highlights the importance of the development of employee retention strategies from a sound theoretical base. Whilst this is certainly applicable to the university as an organization, empirical data remains sparse. Similarly, some work has considered the relationship between program knowledge and the value of work-family practices in organizational commitment, suggesting that the importance of employee perceptions of workfamily practices is vital and a key part of organizational commitment (Haar \& Spell, 2010). Whilst pertinent to university faculty, findings from Haar and Spell (2010) are more general in nature. In the same vein, a recent Good Day at Work report underlined personal responsibility and trust on the part of employees as key to making work-life integration work, but stressed that "this is supported by a strong psychological contract between the employer and employee based on a fair, clear agreement of what the employee is expected to deliver" (Robertson Cooper \& Bank Workers Charity, 2017, p. 1). An approach that regards the two domains as complementary rather than in competition can thus diminish work-life stress. 
Supplementary work from Nonis and Owens-Swift (2001) explored the link between academic dishonesty and propensity for workplace dishonesty amongst students. Whilst this study is slightly tangential - given that academic dishonesty could per se be regarded as workplace dishonesty amongst university faculty - the results are pertinent to this work. Specifically, the authors concluded that where students did not respect the climate of academic integrity in their place of study, the likelihood that they would respect professional integrity in their future workplace is decreased. This finding is important for two reasons, suggesting both a direct impact of lack of organizational commitment amongst university faculty and potentially an impact on future university faculty who are current students.

With the UK enjoying improved employment rates, organizations are hard pressed to attract and retain talent (Office for National Statistics, 2016). As such, national and international employers alike need to better understand employee needs and wants to inform their talent strategies and maintain a competitive edge (Robertson Cooper \& Bank Workers Charity, 2017). Here again, research shows that high-trust organizations are mindful of the need for work-life balance and integration, which in turn improves employee performance (Unum, 2013).

South Africa. As a result of South Africa's colonial and apartheid past, social inequality was a feature of every facet of South African existence; but following South Africa's 1994 democratic election, various transformation-oriented schemes have been suggested and implemented. These include higher education also (Badat, 2010).

Ngidi and Sibaya (2002) asserted that the South African educational system was in a "transitional stage". They further argued that a lack of discipline in universities, unmotivated learners, retrenchments of white academics and retirement packages for academics, and large pupil-educator ratios all contribute to raising the stress levels of educators in South Africa. Paulse (2005) added the management style of institution heads and corruption in certain academic institutions as causes of stress to educators in South Africa.

Ngidi and Sibaya (2002) and Steyn (2002) illustrated that academics in particular have to cope with "poor physical conditions" such as overcrowding, inadequate equipment, and lack of adequate facilities. Yousef (2000) argued that academics' tardiness, absenteeism, and turnover, which greatly affect an institution, are symptoms of undesirable organizational commitment and job dissatisfaction in South Africa.

The "endemic of dissatisfaction" in the academic profession identified by Khadijeh and Abrisham (2011) appears to be more pronounced in South African rural areas. Bull (2005) noted that in research done, nearly $50 \%$ of South African rural academics are dissatisfied with their working conditions. When compared to the private sector and positions requiring the same level of expertise, South African academics are inadequately remunerated (Badat, 2010). As result of this, many educators leave or consider leaving institutions for work in the private sector. Bull (2005) presented the following factors as being the possible causes of academic attrition: a lack of recognition, limited opportunities for promotion, excessive paperwork, lack of autonomy, lack of supplies, low pay, and stressful interpersonal interactions.

South African academics, like employees in other organizations, desire decent salaries and benefits, suitable working conditions, recognition, and promotion opportunities (Bull, 2005). There are poor academic results, poor conditions in many universities and an inferior quality of education that, in general, raise concerns regarding the attitudes of academics towards their jobs. Bagraim (2004) echoes this view when he points out that there is a "prevailing consensus" that claims that academics are not committed to their institutions. As a result of this assumption and 
general consensus, academics may not be as committed, derive lower satisfaction from their jobs, display higher absenteeism rates and their performance may be impeded (Bull, 2005).

Contrary to popular belief, perhaps exacerbated by the negative reports by the media as asserted by Bull (2005); Bagraim (2004) argues that on the whole, organizational commitment levels amongst academics in South Africa are high and that many surveyed academics disagreed that academics on the whole were "highly individualistic and self-interested employees" (p. 300). Bagraim (2004) affirmed that in this case, organizational commitment is not affected by factors such as downsizing (corporate disloyalty), portfolio careers, or new work values, etc., but rather the academic's particular work conditions. Bagraim (2004) further affirmed in a study that over $70 \%$ of surveyed academics expressed their "intention to remain in South Africa" (p. 268).

United States. In the North American region, earlier studies of organizational commitment typically looked for relationships between commitment levels of employees and various consequences of value to the organization, such as turnover, absenteeism, and job effort (Mathieu \& Zajac, 1990; Riketta, 2002). In fact, between 1985 and 2000, over 70 articles, dissertations, and other empirical research dealing with the concept of organizational commitment had been published (Meyer, Stanley, Herscovitch, \& Topolnytsky, 2002). The more recent studies have looked at organizational commitment among boards of directors (incorporating corporate governance theories), flexible work schedules (telecommuters/telework), and volunteers rather than exclusive paid employees.

Stephens, Dawley, and Stephens (2004) found a strong association between the directors' potential for participation in control, service, and resource dependence roles on the board, and affective and normative commitment. They found that those in elected leadership board roles possessed higher levels of affective and normative commitment. They also found that normative and affective commitment enhances self-reported performance among volunteers. Hunton and Norman (2010) found that task performance was positively associated with organizational commitment, and organizational commitment mediated the relationship between the telework conditions and task performance. They administered the Meyer, Allen, and Smith (1993) revised three-component model of organizational commitment to investigate the impact of four specific telecommuting strategies on the affective, continuance, and normative commitments of medical coders in the health care industry. They found that the instrument exhibited satisfactory convergent and divergent validity in a longitudinal field setting.

A number of studies have also reported significant correlation between affective organizational commitment and affective professional commitment of employees (Blau \& Holladay, 2006; Dwivedula \& Bredillet, 2010; Fu, Bolander, \& Jones, 2009). Blau and Holladay (2006) found that affective commitment showed a stronger relationship to professional withdrawal intentions and to a lesser extent professional development activities. Fu, Bolander, and Jones (2009) found that affective commitment has a positive direct effect on sales effort, whereas normative and continuance commitment do not. However, they also found that normative commitment plays a supporting role as it positively moderates the relationship between affective commitment and effort. Moreover, they found that job satisfaction has positive effects on both affective and normative commitment, but no significant effect on continuance commitment.

\section{Methodology}

In order to assess cross-national trends in HR practices for university employees, we received permission from Smeenk, Eisinga, Teelken, and Doorewaard (2006) to use the survey instrument 
cited in their edited text and utilized to assess organizational commitment among European university employees (the 2006 Data Archiving and Networking Services (DANS)). This instrument was first used in 2004 to examine predictors and consequences of organizational commitment for a survey group of almost 9,600 respondents in six European countries.

Similarly, we utilized the survey with over 600 potential respondents in 14 universities spanning 10 countries around the world (United States, Lebanon, Greece, Malaysia, South Africa, India, Nigeria, United Kingdom/Scotland, Italy, and Russia). To deploy this survey instrument, we employed an online survey tool, SurveyMonkey (www.surveymonkey.com), in early 2012. Both email invitations from the survey tool and personal, individual emails — with a link to the survey - were sent in order to collect responses. This was done because some universities allowed us to send emails to potential respondents directly while other universities preferred to have an internal resource send the link to the survey to potential respondents in order to avoid "spam" perceptions and to increase response probability.

A total of four email-based invitations were sent from the survey tool from March 1, 2012 to May 1, 2012. Both partial and complete survey responses were captured, and all results were de-identified before analysis to ensure confidentiality. Only the institution from which a respondent came was known to the data analyst. Specific statistics regarding sample sizes and response rates are shown in the next section as well as overall results from statistical analyses performed.

Once the survey was closed in May 2012, summary statistical analyses were conducted to determine key trends and significant differences in response behaviors by region. Analyses were conducted using both the "Response Summary" features of SurveyMonkey (within the webbased survey tool environment) and STATA 11 statistical software.

\section{Results}

\section{Sample characteristics}

A total of 616 email-based invitations were distributed to potential respondents across 14 universities pre-selected and pre-approved by the research team. Pre-approval was necessary to ensure email acceptance and so some university HR heads could inform potential respondents of the survey/research validity/university approval. In some cases, universities wished to distribute the survey, themselves, via email - instead of having respondents receive an email directly from the survey tool. This was facilitated by providing university administrators with a link to the survey that could then be emailed by someone within the university. Again, this helped to increase the probability of survey acceptance and completion by coming from someone "inside" the university instead of from SurveyMonkey directly. Statistics for survey responses are shown below:

- $\quad$ Total survey emails sent (from SurveyMonkey; does not include emails with link sent by others): 616

○ Non-response (after three additional reminder emails): 506

- Total responses received from SurveyMonkey invitations: 110

- Completed surveys: 70

- Partial surveys: 40

- $\quad$ Additional surveys received from email-based links sent to potential respondents: 29

○ Completed surveys: 18

○ Partial surveys: 11 
Thus, overall, we received 139 surveys, or a response rate of approximately $22.6 \%$. This is only an approximation since we do not know how many emails with survey links were sent to potential respondents outside of the SurveyMonkey tool.

Of the 139 survey results received, 88 of them were completed in full $(63.3 \%$ of those received; $14.3 \%$ of total surveys distributed by the SurveyMonkey tool). Of the 14 universities surveyed, 11 were represented in the responses. Note that six respondents did not answer this first question (university affiliation), and two entered "other" as their university. These eight responses were discarded and, as such, a total sample size of 131 responses was analyzed.

\begin{tabular}{|l|c|}
\hline Athens University of Economics and Business (Greece) & 41 \\
\hline Bryant University (USA) & 16 \\
\hline Lebanese American University (Lebanon) & 0 \\
\hline MARA University of Technology (Malaysia) & 2 \\
\hline Motilal Nehru National Institute of Technology (India) & 15 \\
\hline Nelson Mandela Metropolitan University (South Africa) & 11 \\
\hline Nnamdi Azikiwe University (Nigeria) & 8 \\
\hline Queen Margaret University (Scotland) & 0 \\
\hline Teguh SNR Management Consulting (Malaysia) & 0 \\
\hline Universiti Putra Malaysia UPM (Malaysia) & 4 \\
\hline University Kebangsaan (Malaysia) & 4 \\
\hline University of Bergamo (Italy) & 19 \\
\hline University of Malaya (Malaysia) & 1 \\
\hline Washburn University (USA) & 12 \\
\hline Other & 2 \\
\hline Unanswered & 6 \\
\hline
\end{tabular}

Note that even though only 88 of the 131 total survey responses assessed were completed in full, we chose to use partial survey responses in order to increase sample sizes for certain questions.

Given the relatively low per-university response counts, we determined that further crosstabulations - and, in fact, cross-country comparisons of detailed subsets - may not be possible. Instead, we decided to treat the entire response group as a single sample and to only note, where sample sizes and significance permit, specific interesting cross-country or cross-continent differences. In general, however, low sample-size characteristics make matrix modeling of such cross-country comparisons impossible. Cross-continent comparisons are possible; however, we believe such a cross-tabulation is too general to be of any specific interest here.

\section{Faculty composition, management, and work ethic}

Across the survey group, the vast majority of respondents were assistant professors $(n=34)$, associate professors $(n=28)$, lecturers $(n=28)$, or full professors $(n=25)$. The average year of initial employment at their universities, 1984, indicates long tenures by some respondents (28 years as of 2012; $n=126)$. However, average years in current role is much shorter at 7 years $(n=126)$. These long-term employees work, on average, 37.9 hours per week $(n=126)$.

The majority of respondents who identified their gender $(n=102)$ responded as male (71\%), and the average age of the respondent pool was 43.6 years (again, of the 102 respondents 
who disclosed their ages). Of the 102 respondents who answered questions about publication rates over the past five years, an average of 137 articles were published in peer-reviewed journals, 239 in non-refereed professional or trade journals, 267 chapters in books, and 285 texts or other books. These 102 respondents also reported that almost 300 research reports, on average, had been disseminated by them to internal colleagues and/or external clients.

Some interesting trends emerged when we studied participants' responses to questions involving sizes and pressures of faculty members over time. When asked whether a statement applied in a range from "not at all" to "completely", most responses, in aggregate $(n=119)$, were middle-of-the-road (i.e., "applies to some extent"). However, some strong agreements, either "agree to a large extent" or "agree completely", were seen with these statements:

- The faculty is under pressure to reduce expenditures $(n=65$ for top two categories of agreement).

- Numbers of enrollments to the faculty has increased since I started working here $(\mathrm{n}=57)$.

- $\quad$ Faculty is under pressure to compete with similar faculties at other universities $(n=56)$.

Conversely, strong negative agreement ("does not apply at all" or "applies very little") was seen with these statements:

- The faculty has increasingly applied private sector management techniques, such as performance management and efficiency controlling $(n=66$ for bottom two categories of agreement).

- In the faculty, the evaluation of teaching and research is mainly carried out with assessment criteria set by "the managers" rather than by "peers" $(n=52)$.

Thus, we note that while faculties are increasing in size, they are also being forced to spend less while competing with other faculties at competing schools. This may have led to more private sector performance management emphasis - and "scorecarding" — but with evaluation criteria still largely driven by peers, not managers. This is an interesting result in that these "business" pressures are being applied and measured, using outside/private sector techniques, but measured largely by internal, peer-driven criteria. This may point to a disconnect between the teaching and research goals/success criteria set by academic peers and the overarching, external business goals being driven more and more into faculty performance management and measurement.

When asked a series of questions regarding attitudes toward work ethics — including how hard they work, under what conditions they work, etc. (Question 7) - respondents almost always replied in one of the top two agreement areas ("agree somewhat" and "totally agree"). Of the 114 responses to this question, almost universal agreement was seen regarding the importance of doing a good job "as best as one can" (92.1\% totally agree). Fortunately, too, over half of respondents $(51.8 \%)$ replied "totally agree" that they have the possibility of independent thought in their jobs.

However, interesting counterpoints were seen in terms of faculty modally replying that they "agree somewhat" that they have to work hard even if they don't like the work, that they do things that should be done in different ways, and/or that they work under incompatible policies and guidelines. These are important to note since even if faculty perceive work freedom and opportunities for independent thought, they have these perceptions in the context of conflicting 
policies, and, at times, while having to do work they do not enjoy or that may not be completed in optimal ways. We believe these results, when coupled with those from Question 6, point to an interesting conundrum: the more that faculties are "performance managed", while setting their own success criteria for teaching and research, the more they may perceive conflicting/confusing policies, suboptimal processes, and the need to do undesirable work in an otherwise "enjoyable" environment that promotes job freedom and independent thought.

While it is no secret that many faculty members enjoy the relative freedoms of academia, it is clear that some (private sector) management approaches stifle, somewhat, these freedoms and historically carefree attitudes relative to (business) "controls" of academic departments, budgets, reporting structures, and personnel decisions. Increasingly more common are more strict budgetary and fiscal controls, hiring guidelines and checks-and-balances, and oversight for departmental (and perhaps teaching and research) administration. More and more universities are implementing grant, teaching, and research evaluation programs - to more tightly control spending and quality in these areas - and to be more "lean" in terms of spending, staffing, and administrative costs related to core teaching and research duties of faculty. Such conflict is seen, especially in long-tenured faculty, between academic freedom and the need for improved/stricter controls.

Faculty salaries, on-the-job training, and sense of community

In terms of salaries and on-the-job training, roughly half of respondents (56 of 111) noted that their salaries were inferior to their levels of effort. Further, most noted that they received on-thejob training not directly related to their current job roles. Perhaps this indicates, again, that faculty are spending more time on administrative tasks — and the training required to complete them - than on skills and tasks more directly related to their perceived focus (of, presumably, teaching and research). To this point, when asked about freedoms in defining job roles, etc., between 28 and 39\% (of $n=111$ ) "agreed to a large extent" that they determined their own work flows, could initiate new teaching and research efforts, and felt that employees should be more involved in day-to-day operational decisions. Thus, again, we see evidence that while faculty and administrators may have solid control over their own spheres of influence and job scopes, broader administrative and decision-making authority and involvement is likely reserved for others.

Of the 107 who replied to questions regarding involvement within (and beyond) the scopes of their departments, over 74\% noted that they felt a part of their departments ("agree somewhat" or "agree completely"). Similar response profiles were noted regarding feeling membership in their faculties/administration, about feeling informed about what is going on in the faculty, and about feeling informed about changes that affect their jobs. However, lower agreement was seen among the group when it came to doing enough to avoid faculty layoffs. This again points to potential control conflicts between overall administration and decision making and more focused, goal/task-oriented accomplishment and information.

When asked to pinpoint views of top management at their institutions, 107 participants answered, and over a third (34.6\%) felt that middle management had little care for employees or for the broader interests of the organization. The second most frequent response $(28.0 \%)$ indicated that management cared nothing of employees and only about the broader institutional needs. Thus, almost two thirds of respondents noted little care of management for employee interests (and only marginal focus on institutional needs). Encouraging, though, was the $24.3 \%$ of respondents who noted that management was "ideal" in the sense that both employees and institutional needs were embraced well and equally. 


\section{Faculty performance and collegiality}

In contrast, though, were the positive viewpoints that management shared with respect to how they were assessed, in terms of performance, and their sense of collegiality — and of community — with each other, in terms of personal relationships, dependence, and "fair treatment" of each other. Forty-nine percent of the 105 respondents asked to compare a focus on "control and an emphasis on accountability and performance measurement" vs. one on "individual strengths and weaknesses with development of competencies" said the former (emphasis on control and performance measurement) was either dominant or prevalent, in terms of styles, with the remaining respondents noting that these two styles were either used in equal measure $(27 \%$, rounded) or that the latter treatment (competence development) was more prevalent (25\%, rounded). Thus, faculties are still split, somewhat, on whether a "command and control" system of leadership prevails over a more competence-building, learning-focused organization that prevails in today's universities.

However, when asked to respond to questions regarding dependence on coworkers, friendships, and helping to assist with the larger aims of the faculty, the majority of respondents $(n=105)$ either agreed somewhat or totally agreed that their contributions were important for the larger aims of the faculty (79\%), they were able to talk to colleagues about more than just business (77\%), and that they had the opportunity to support their colleagues in their research and teaching (76\%). However, the two lowest-ranked responses - colleagues' trust of each other ( $41 \%$ top two boxes) and a sense that everyone is treated fairly on the faculty (31\%) indicate that trust and fairness remain issues, at an organizational level, even though friendships and support were highly rated. This may indicate that while colleagues may enjoy working with each other and enjoy helping each other, a sense of trust and fairness is not always evident — or evidenced - from the same colleagues or from managers/leaders. Another lower-ranked response - about the faculty having clear rules that everyone is expected to follow - also reinforces the relative lack of "fairness" (or perception of it) and that, even though standard management practices may be imported into operations, not everyone may be seen as following them consistently.

\section{External attitudes and job security}

Finally, when 104 respondents answered questions regarding their faculty/administration job satisfaction and security, some interesting - and often personal - comments and trends emerged. The highest-rated responses, when considering the top two boxes of "agree somewhat" and "totally agree", included enjoyment of discussing faculty with people outside of the faculty (69\%), being happy to spend the rest of their careers with the faculty (62\%), finding it difficult to leave the faculty right now $(61 \%)$, and being afraid of what might happen if they quit their jobs without having another one lined up (58\%). These results seem to indicate that although faculty are quite content where they are — and praise their situations to outsiders — they may be afraid, privately, about the job market in terms of finding another position either by choice or by necessity.

However, the same respondents seemed relatively comfortable in their options to pursue other opportunities given relative disagreement with statements regarding moving from organization to organization too often (51\% totally disagreed or disagreed somewhat), being able to leave the faculty at no cost right now $(56 \%)$, or having too few options to consider leaving $(40 \%)$. This is an interesting contradiction in the results; the same faculty who may be afraid of what to do if their jobs were to disappear also disagree that there are no other options or that it would be difficult to jump to another position. We believe that this contradiction is nothing 
more, however, than faculty having, perhaps, private fears about job security, but rather public displays of optionality when it comes to needing another position. This is notable, though, for managers and leaders who are seeking to build more secure organizations while also promoting skill development and competency building in the event that other opportunities come along for employees.

\section{Discussion}

The study examines the phenomenon of organizational commitment in the cross-national or cross-cultural context. The results imply that, in general, there does exist an invariance in affective commitment, continuance commitment, and normative commitment across cultures. A trend emerged in the study regarding the impact of various factors - like compensation, training, management style, autonomy, fairness, trust participation in decision making — on organizational commitment, which points to some degree of similarity in attitude of employees towards organizational commitment in different cultures. In the background there exists the phenomenon of globalization and the changing management practices with increasing emphasis on private sector practices, particularly, and focus on performance. Continuance commitment was found to be high across the countries studied for which data was collected and the need for security emerged high across the cultures. Affective commitment appeared to be high, but globalization and resultant changes (need to prove excellence, reduce expenditures, etc.) in organizations seem to be having an impact on faculty attitudes of organizational commitment. Normative commitment appeared to be high among the faculty members, though it was moderated by perceptions of trust and fair treatment in the workplace. The study brings out the need for a deeper understanding of invariance in organizational commitment (inter alia, through the three-component model), and in particular contributes to our understanding of the relationship between organizational commitment and its various antecedents, including HRM practices, for faculty in higher education.

This study's findings thus have important implications for both theory and practice. Particularly, they imply that though certain differences may exist between different countries and cultures with respect to Meyer and Allen's three-component model of organizational commitment, there is strong evidence of the existence of invariance and thus generalizability of the model across cultures. Personal cultural orientation does not seem to affect affective commitment, normative commitment, and continuance commitment too much. Also, the threecomponent model cannot be examined in isolation without considering the antecedents as discussed in the study, including the background context, which here is globalization.

With regard to practice, the pattern of affective commitment, continuance commitment, and normative commitment that our research highlights has implications for managers. The findings seek to help institutes of higher education in adopting a more strategic approach towards designing policies for faculty members. HR managers need to be taking care of aspects like salary, training, job security, and fairness at work. Results of the present study corroborate the findings of previous research (Dunham, Grube, \& Castaneda, 1994; Allen \& Fifield, 1999; Rowley \& Sherman, 2001) that faculty members appreciate freedom at work. Policies need to be designed to strike a balance between independence at work and "performance focus" resulting from increased competition. Management must take such actions and design such policies as can make employees feel "connected" with the organization and get a feeling that management is concerned with employee interests. In this area and as with the findings of other studies, so too this research can support policymaking in the education sector through enhanced understanding 
of the influence of leadership style and organizational culture on the motivation, satisfaction and commitment of employees (Al-Sada et al., 2017). Further, public policy that supports research and career development for national as well as expatriate faculty can prove a major contribution to organizational commitment (Ayari-Gharbi et al., 2014). Efforts need to be made to increase an environment of trust and fairness. Today, when employees are coming from diverse cultural backgrounds in the organizations, the findings of the study indicate that to some extent the same policies may work for a culturally diverse workforce for increasing commitment. Since commitment is negatively related to withdrawal and turnover (Meyer \& Allen, 1996) and positively related to job performance (e.g., Meyer, Paunonen, Gellatly, Goffin, \& Jackson, 1989), appropriate HR policies may help in retaining the talented faculty members and enhancing their performance in universities.

The results of the study also have implications for employees. The findings indicate that the impact of globalization has been felt on work practices in universities, irrespective of the country. Faculty members cannot avoid the changes in the workplace and therefore need to be more adaptive to a changing work environment and management practices to enhance their commitment towards their organization. Since affective commitment has been found to be related to employee stress and work-family conflict outcomes (Meyer, Stanley, Herscovitch, \& Topolnytsky, 2002), having high commitment may also improve overall quality of life of employees.

\section{Conclusion and Recommendations for Further Research}

Although we did not receive enough responses to warrant a true cross-national study of hiring and employment trends and attitudes among university faculty and administrators, we were able to note some surprisingly consistent responses regarding compensation, workplace attitudes, work ethics, sense of community and collegiality, and the interesting duality of private vs. public views of job security. Given that the response cohort was relatively senior - in terms of professorial ranking, publication success, years of faculty/administration employment, and sheer age - we find some of the results expected (e.g., attitudes toward outside "management" techniques), but others remarkable (e.g., job security and sense of fairness/equity in the administration).

Moving forward, there is a need for more in-depth research regarding specific, nationallevel behaviors and attitudes to see if any of this study's results may differ by cultural orientation, university leadership style, etc. Further, longitudinal research — by looking at results of the same cohort of respondents over time - would be helpful to see if attitudes change as job roles, seniority, and exposure to more management duties tempers any of these outcomes. In addition, a stratified sampling approach - comparing different job grades and faculty levels over time - could also lead to interesting comparisons and contrasts among belief systems of junior vs. senior faculty, administrator vs. faculty roles, and teaching vs. research-oriented faculty.

\section{References}

Adeyemo, D.A. (2000). Job Involvement, Career Commitment, Organizational Commitment and Job Satisfaction of the Nigerian Police. A Multiple Regression Analysis. Journal of Advance Studies in Educational Management, 5(6), 35-41. 
Ahiauzu, A. \& Asawo, S.P. (2009). Altruistic Love Culture and Workers Commitment in the Nigerian Manufacturing Industry: A Study in Workplace Spirituality. Proceedings of the $10^{\text {th }}$ Annual Conference of International Academy of African Business and Development.

Akintayo, D.I. (2005). The impact of demographic factors on organizational commitment of industrial workers in Lagos State, Nigeria. International Journal of Emotional Psychology and Sport Ethics, 7, 32-41.

Al-Sada, M., Al-Esmael, B., \& Faisal, M. N. (2017). Influence of organizational culture and leadership style on employee satisfaction, commitment and motivation in the educational sector in Qatar. EuroMed Journal of Business, 12(2), 163-188. https://doi.org/10.1108/EMJB-02-2016-0003

Allen, D.K. \& Fifield, N. (1999). Re-engineering change in higher education. Information Research, 4(3). Retrieved from: http://informationr.net/ir/4-3/paper56.html

Allen, N.J. \& Meyer, J.P. (1990). The measurement and antecedents of affective, continuance and normative commitment to the organization. Journal of Occupational Psychology, 63, $1-18$.

Allen, N.J. \& Meyer, J.P. (1996). Affective, continuance and normative commitment to the organization: An examination of construct validity. Journal of Vocational Behaviour, 49, 252-276.

Ayari-Gharbi, A., Besson, D., \& Mamlouk, Z. (2014). Organizational commitment expatriates Case of university teachers. XXVième Congrès de l'AGRH Chester, Grande-Bretagne 6 \& 7 November 2014. Retrieved from: https://www.agrh.fr/assets/actes/2014-AyariGharbi-Besson-Mamlouk.pdf

Badat, S. (2010). The challenges of transformation in higher education and training institutions in South Africa. Development Bank of Southern Africa.

Bagraim, J.J. (2004). The Improbable Commitment: Organizational Commitment amongst South African Knowledge Workers. University of Warwick, Warwick Business School.

Bakhshi, A., Kumar, K., \& Rani, E. (2009). Organizational Justice Perceptions as Predictor of Job Satisfaction and Organizational Commitment. International Journal of Business Management, 4(9), 145-154.

Balasubramanian, A.G. (1995). Evolution of the Personnel Function in India--A ReExamination-Part II. Management and Labour Studies, 20(1), 5-14.

Ballout, H. I. (2009). Career commitment and career stress: Moderating role of self efficacy. Career Development International, 14(7), 655-670.

Balogun, S.K., Oladipo, S.E., \& Odekunle, S. (2010). Influence of Job Esteem and Job Status on Organizational Commitment of Employees of Selected Banks in Nigeria. Academic Leadership, 8, 2.

Bashir, N., \& Long, C.S. (2015). The relationship between training and organizational commitment among academicians in Malaysia. Journal of Management Development, 34(10), 1227-1245. https://doi.org/10.1108/JMD-01-2015-0008

Bayona-Sáez, C., Goñi-Legaz, S., \& Madorrán-García, C. (2009). How to raise commitment in public university lecturers. International Review of Administrative Sciences, 75(2), 333347.

Bhatnagar, J. (2005). The power of psychological empowerment as an antecedent to organizational commitment in Indian managers. Human Resource Development International, 8, 419-433. 
Bhatnagar, J. (2008). Predictors of organizational commitment in India: Strategic HR roles, organizational learning capability and psychological empowerment. Human Resource Management International Digest, 16(3), 1782-1812.

Bird, B.J. \& Allen, D.N. (1989). Faculty Entrepreneurship in Research University Environments. The Journal of Higher Education, 60, 583-596.

Blau, G. \& Holladay, E. (2006). Testing the discriminant validity of a four-dimensional occupational commitment measure. Journal of Occupational \& Organizational Psychology, 79(4), 691-704.

Bourantas, D. (1988). Leadership styles, need satisfaction and the organizational commitment of Greek managers. Scandinavian Journal of Management, 4, 121-134.

Bourantas, D. \& Nicandrou, I.I. (1998). Modelling post-acquisition employee behavior: Typology and determining factors. Employee Relations, 20(1), 73-91.

Bourantas, D. \& Papalexandris, N. (1992). Variables affecting organizational commitment. Journal of Managerial Psychology, 7(1), 3.

Bourantas, D. \& Papalexandris, N. (1999). Personality traits discriminating between employees in public- and in private-sector organizations. International Journal of Human Resource Management, 10(5), 858.

Bourdieu, P. (1999). Social conditions of the international circulation of ideas. In R. Shusterman (ed.), Bourdieu: A Critical Reader (pp. 220-229). Oxford: Wiley-Blackwell Publishers.

Bozionelos, N. \& Kiamou, K. (2008). Emotion work in the Hellenic frontline services environment: How it relates to emotional exhaustion and work attitudes. International Journal of Human Resource Management, 19(6), 1108.

Bresciani, S., Thrassou, A., \& Vrontis, D. (2012). Human resource management-practices, performance and strategy in the Italian hotel industry. World Review of Entrepreneurship, Management and Sustainable Development 3, 8(4), 405-423.)

Buchko, A., Weinzimmer, L., \& Sergeyev, A. (1997). A comparative analysis of organizational commitment between workers in the United States and Russia. Journal of Managerial Issues, 9(2), 204-215.

Buchko, A., Weinzimmer, L., \& Sergeyev, A. (1998). Effects of cultural context on the antecedents, correlates, and consequences of organizational commitment: A study of Russian workers. Journal of Business Research, 43(3), 109-116.

Budhwar, P.S. (2009). Human resource management in the Indian context. In P.S. Budhwar \& Bhatnagar, S. (eds.), The Changing Face of People Management in India. London: Routledge.

Bull, I.H.F. (2005). The relationship between job satisfaction and organizational commitment amongst high school teachers in disadvantaged areas in the Western Cape. University of the Western Cape, South Africa.

Charlier, J. É., \& Croché, S. (2016). Higher education: from" unclear technologies" to human resources management techniques. Normand Romuald, Derouet Jean-Louis (dir.).

Chughtai, A.A. \& Zafar, S. (2006). Antecedents and consequences of organizational commitment among Pakistani university teachers. Applied Human Resource Management Research, 11(1), 39-64.

Cooper-Hakim, A. \& Viswesvaran, C. (2005). The construct of work commitment: Testing an integrative framework. Psychological Bulletin, 131(2), 241-259. 
Crossman, A. \& Abou-Zaki, B. (2003). Research note. Job satisfaction and employee performance of Lebanese banking staff. Journal of Managerial Psychology, 18(4), 368376.

Dalal, R.S. (2005). A meta-analysis of the relationship between organizational citizenship behavior and counterproductive work behavior. Journal of Applied Psychology, 90(6), 1241-1255.

De Witte, H. \& Näswall, K. (2003). 'Objective' vs 'subjective' job insecurity: Consequences of temporary work for job satisfaction and organizational commitment in four European countries. Economic and Industrial Democracy, 24(2), 149-188.

Deem, R. (1998). 'New managerialism' and higher education: The management of performances and cultures in universities in the United Kingdom. International Studies in Sociology of Education, 8(1), 47-70.

Deem, R. (2001). Globalization, new managerialism, academic capitalism and entrepreneurialism in universities: Is the local dimension important? Comparative Education, 37(1), 7-20.

Dimitriades, Z.S. (2011). Organizational commitment: A profile analysis. Paper presented at the 2011 European Academy of Management Conference, Tallinn, Estonia.

Dimitriades, Z.S. \& Papalexandris, N. (2012). Job and organizational attitudes in relation to financial performance in Greek retail banking: An exploratory empirical investigation. International Journal of Human Resource Management, 23(4), 793.

Dirani, K.M. (2009). Measuring the learning organization culture, organizational commitment, and job satisfaction in the Lebanese banking sector. Human Resource Development International, 12(2), 189-208.

Dunham, R.B., Grube, J.A., \& Castaneda, M.B. (1994). Organization commitment: The utility of an integrative definition. Journal of Applied Psychology, 79, 370-380.

Dwivedula, R. \& Bredillet, C.N. (2010). The relationship between organizational and professional commitment in the case of project workers: Implications for project management. Project Management Journal, 41(4), 79-88.

Eisenberger, R., Fasolo, P., \& Davis-LaMastro, V. (1990). Perceived organizational support and employee diligence, commitment and innovation. Journal of Applied Psychology, 75, 5159

Eisinga, R., Telkeen, C., \& Dooreward, H. (2010). Assessing Cross-National Invariance of the Three-Component Model of Organizational Commitment: A Six-Country Study of European University Faculty. Cross Cultural Research, 44(4), 341-373.

Epitropaki, O. (2003). Transformational leadership, psychological contract breach and organizational identification. Paper presented at the Academy of Management Proceedings. doi:10.5465/AMBPP.2003.13792488

Epitropaki, O. \& Martin, R. (2005). From ideal to real: A longitudinal study of the role of implicit leadership theories on leader-member exchanges and employee outcomes. Journal of Applied Psychology, 90(4), 659.

Etzkowitz, H. (2008). The Triple Helix. University-Industry-Government, Innovation in Action. London: Routledge.

Farrell, D. \& Stamm, C.L. (1988). Meta-Analysis of the Correlates of Employee Absence. Human Relations, 41(3).

Folger, R. \& Konovsky, M. (1989). Effect of procedural and distributive justice on reactions to pay raise decisions. Academy of Management Journal, 32, 115-130. 
Fu, F.Q., Bolander, W., \& Jones, E. (2009). Managing the drivers of organizational commitment and salesperson effort: An application of Meyer and Allen's three-component model. Journal of Marketing Theory and Practice, 17(4), 335-350.

Futhey, T., Luce, R., \& Smith, J.M. (2010). Drivers of change in Higher Education. Educause Review, 45(1), 12-13.

Gaertner, K.N. \& Nollen, S.D. (1989). Career experiences, perceptions of employment practice and psychological commitment to the organization. Human Relations, 42, 975-991.

Gbadamosi, L. \& Nwosu, J.C. (2011). Entrepreneurial intension, organizational justice and job satisfaction as determinants of employees' organizational commitment: Evidence from Babcock University Nigeria. Proceedings of Informing Science \& IT Education Conference (InSITE) 2011.

Gianecchini, M., Imperatori, B., Grandori, A., \& Costa, G. (2008). How typical are "a-typical" employment contracts? An organizational perspective. Working Paper, University of Padova, Italy.

Giannikis, S.K. \& Mihail, M. (2008). Predicting organizational commitment: A field study of full-time and part-time retail employees. The Business Review, Cambridge, (10), 69-78.

Glazer, S., Daniel, S.C. \& Short, K.M. (2004). A Study of the Relationship between Organizational Commitment and Human Values in Four Countries. Human Relations, 57(3), 323-345.

Glinia, E., Costa, G., Mavromatis, G., Tsitskari, E., \& Kalaitzidis, V. (2004). Sport tourism and organizational behaviour by seasonal employees in resort hotels. Journal of Sport \& Tourism, 9(2), 203.

Goldstein, P.J. (2006). The future of Higher Education: A view from CHEMA. Retrieved from: http://net.educause.edu/ir/library/pdf/ECP0602.pdf

Haar, J.M. \& Spell, C.S. (2010). Programme Knowledge and Value of Work-Family Practices and Organizational Commitment. International Journal of Human Resource Management, 15(6), 1040-1055.

Hawkins, B.L. (2008). Accountability, Demands for Information and the Role of the Campus IT Organization. In R.N. Katz (ed.), The Tower and the Cloud (pp. 98-104). Educause, USA. Retrieved from: http://www.educause.edu/thetowerandthecloud

Henkin, A.B. \& Marchiori, D.M. (2003). Empowerment and organizational commitment of chiropractic faculty. Journal of Manipulative Physiological Therapeutics, 26(5), 275281.

Hofstede, G. (2001). Culture's consequences: International differences in work-related values (2nd ed.). London: Sage Publications.

House, R.J., Hanges, P.J., Javidan, M., \& Dorfman, P.W. (2004). Culture, leadership and organizations: The globe study of 62 societies. London: Sage Publications.

Hunton, J.E. \& Norman, C. (2010). The impact of alternative tele-work arrangements on organizational commitment: Insights from a longitudinal field experiment. Journal of Information Systems, 24(1), 67-90.

Igbeneghu, B. \& Popoola, S.O. (2011). Influence of locus of control and job satisfaction on organizational commitment: A study of medical records personnel in university teaching hospitals in Nigeria. Library Philosophy and Practice. Retrieved from: http://digitalcommons.unl.edu/cgi/viewcontent.cgi?article=1606\&context=libphilprac 
Jacob, M., Lundqvist, M., \& Hellsmark, H. (2003). Entrepreneurial transformations in the Swedish University system: The case of Chalmers University of Technology. Research Policy, 32, 1555-1568.

Jha, S. (2011). Influence of psychological empowerment on affective, normative and continuance commitment: A study in the Indian IT industry. Journal of Indian Business Research, 3(4), 263-282.

Karim, A. \& Noor, M. (2006). Evaluating The Psychometric Properties of Allen \& Meyer's Organizational Commitment Scale: A Cross Cultural Application among Malaysian Academic Librarians. Malaysian Journal of Library \& Information Science, 11(1), 86100.

Katou, A.A. \& Budhwar, P.S. (2008). The effect of business strategies and HRM policies on organizational performance: The Greek experience. Global Business \& Organizational Excellence, 27(6), 40.

Katsikea, E., Theodosiou, M., Perdikis, N., \& Kehagias, J. (2011). The effects of organizational structure and job characteristics on export sales managers job satisfaction and organizational commitment. Journal of World Business, 46(2), 221.

Kauffman Foundation. (2008). The future of the research: University meeting the global challenges of the 21st Century. Conference papers from the Kauffmann-Max Planck Annual Summit Rethinking the Role of the University and Public Research for the Entrepreneurial Age, June 8-11 Bavaria, Germany.

Kaur, K. \& Sandhu, H.S. (2010). Career Stage Effect on Organizational Commitment: Empirical Evidence from Indian Banking Industry. International Journal of Business and Management, 5(12), 141-152.

Khadijeh, A. \& Abrisham, A. (2011). The relationship between job satisfaction and organizational commitment amongst school teachers. Journal of American Science, $7(12)$.

Kumar, K. \& Bakshi, A. (2010). The big five model of personality and organizational commitment: Is there any relationship? Humanity and Social Science Journal, 5(1), 2534.

Kushman, J.W. (1992). The organizational dynamics of teacher workplace commitment: A study of urban elementary and middle schools. Educational Administration Quarterly, 28, 542.

Liu, X.P. \& Wang, Z.M. (2001). The study of organizational commitment and its development mechanism. Nankai Business Review, 4(6), 58-62.

Long, L.L., Fang, L.L., \& Ling, W.Q. (2002). Organizational career management: Measurement and its effects on employees' behavior and feelings in China. Acta Psychology Sinica, 24(1), 97-105.

Longenecker, C.O. (2001). Why managers fail in post-Soviet Russia: Causes and lessons. European Business Review, 13(2), 101.

Luthans, F., McCaul, H.S., \& Dodd, N.G. (1985). Organizational commitment: A comparison of American, Japanese and Korean employees. The Academy of Management Journal, 28(1), 213-219.

Markovits, Y., Davis, A.J., \& van Dick, R. (2007). Organizational commitment profiles and job satisfaction among Greek private and public sector employees. International Journal of Cross Cultural Management, 7(1), 77-99. 
Martin, R., Thomas, G., Charles, K., Epitropaki, O., \& McNamara, R. (2005). The role of leadermember exchanges in mediating the relationship between locus of control and work reactions. Journal of Occupational \& Organizational Psychology, 78(1), 141.

Mathieu, J.E. \& Zajac, D.M. (1990). A review and meta-analysis of ante antecedents, correlates, and consequences of organizational commitment. Psychological Bulletin, 108(2), 171194.

McCaul, H., Hinsz, V., \& McCaul, K. (1995). Assessing organizational commitment: An employee's global attitude towards the organization. Journal of Applied Behavioural Science, 31(1), 80-90.

McElroy, J.C. (2001). Managing workplace commitment by putting people first. Human Resource Management Review, 11, 327-335.

McFarlin, D. \& Sweeney, P. (1992). Distributive and procedural justice as predictors of satisfaction with personal and organizational outcomes. Academy of Management Journal, 35, 626-637.

Messarra, L. \& Karkoulian, S. (2008). Organizational commitment recall in times of crisis. Journal of International Business Research, 7(1), 109-118.

Meyer, J.P. \& Allen, N.J. (1991). A three-component conceptualization of organizational commitment. Human Resource Management Review, 1(1), 61-89. ISSN: 1053-4822

Meyer, J.P. \& Allen, N.J. (1997). Commitment in the Workplace: Theory, Research, and Application. Thousand Oaks, CA: Sage Publications.

Meyer, J.P., Irving, G.P., \& Allen, N.J. (1998). Test of the moderating effect of work values on the relations between early work experiences and organizational commitment. Journal of Organizational Behavior, 19, 29-52.

Meyer, J.P., Stanley, D.J., Herscovitch, L., \& Topolnytsky, L. (2002). Affective, continuance, and normative commitment to the organization: A meta-analysis of antecedents, correlates, and consequences. Journal of Vocational Behavior, 61(1), 20-52.

Meyer, J., Allen, N., \& Smith, C. (1993). Commitment to organizations and occupations: Extension and test of a three-component conceptualization. The Journal of Applied Psychology, 78, 538-551.

Meyer, J.P., Paunonen, S.V., Gellatly, I.R., Goffin, R.D., \& Jackson, D.N. (1989). Organizational commitment and job performance: It's the nature of the commitment that counts. Journal of Applied Psychology, 74(1), 152-156.

Ministry of Education. (2004). Development of Education: National Report of Malaysia. Retrieved from: http://www.ibe.unesco.org/National_Reports/ICE_2004/malaysia.pdf

Morey, A.I. (2004). Globalization and the emergence of for-profit higher education. Higher Education, 48(1), 131-150.

Mowday, R.T., Porter, L.W., \& Dublin, R. (1974). Unit performance, situational factors and employee attitudes in spatially separated work units. Organizational Behaviour and Human Performance, 12(1), 231-248.

Mueller, C., Wallace, J., \& Price, J. (1992). Employee commitment. Work and Occupation, 19(3), 211-236.

Nasr, L. (2010). The relationship between the three components model of commitment, workplace stress and career path application to employees in medium size organizations. Allied Academies International Conference, Proceedings of the Academy of Organizational Culture, Communications, and Conflicts, 15(2), 13-27, Las Vegas. 
Ng, T., Butts, M.M., Vandenberg, R.J., DeJoy, D.M., \& Wilson, M.G. (2006). Effects of management communication, opportunity for learning, and work schedule flexibility on organizational commitment. Journal of Vocational Behavior, 68(3), 474-489.

Ngidi, D.P. \& Sibaya, P.T. (2002). Black teachers personality dimensions and work-related stress factors. South African Journal of Psychology, 32(3), 7-15.

Nigam, A.K. (2008). Impact of Strategic Human Resource Management on the Performance of Firms: A Study of Service Sector Firms in India. PhD thesis. Retrieved from: http://www.iitg.ernet.in/scifac/nachi/public_html/internet/aknsynoweb.htm

Nikandrou, I., Panayotopoulou, L., \& Apospori, E. (2008). The impact of individual and organizational characteristics on work-family conflict and career outcomes. Journal of Managerial Psychology, 23(5), 576.

Nonis, S. \& Owens-Swift, C. (2001). An Examination of the Relationship between Academic Dishonesty and Workplace Dishonesty: A Multi-campus Investigation. Journal of Education for Business, 77(2), 69-77.

Office for National Statistics. (2016). UK Labour Market: February 2016, Retrieved from: http://www.ons.gov.uk/employmentandlabourmarket/peopleinwork/employmentandempl oyeetypes/bulletins/uklabourmarket/february2016

Oladele, R.A. (2005). Organizational commitment, job motivation and locus of control among government workers in Lagos State, Nigeria. Journal of Management Studies, 10(5), 3852.

Opayemi, A.S. (2004). Personal attributes and organizational commitment among Nigerian police officers. African Journal for the Psychological Study of Social Issues, 7(2), 251263.

Painter, J. \& Akroyd, D. (1998). Predictors of organizational commitment among occupational therapists. Occupational Therapy in Health Care, 11(2), 1-15.

Panagiotakopoulos, A. (2011). What drives training in industrial micro-firms? Evidence from Greece. Industrial \& Commercial Training, 43(2), 113.

Panagopoulos, N. \& Dimitriadis, S. (2009). Transformational leadership as a mediator of the relationship between behavior-based control and salespeople's key outcomes: An initial investigation. European Journal of Marketing, 43(7/8), 1008.

Papalexandris, N. (2007). Greece, from ancient myths to modern realities. In J.S. Chhokar, Brodbeck, F.C., \& House, R.J. (eds.), Culture and leadership across the world: The globe book of in-depth studies of 25 societies (pp. 767-802). Mahwah, NJ: Lawrence Erlbaum Associates.

Papalexandris, N., Halikias, J., \& Panayotopoulou, L. (2002). Societal culture and human resource management: Exploring the mutual interaction in Greece. Paper presented at the 2nd International Conference: Human Resource Management in Europe: Trends and Challenges, Athens.

Paul, A.K. \& Anantharaman, R.N. (2004). Influence of HRM practices on organizational commitment: A study among software professionals in India. Human Resource Development Quarterly, 15(1), 77-88.

Paulse, J. (2005). Sources of occupational stress for teachers, with specific reference to the inclusive education model in the Western Cape. Faculty of Economic and Management Sciences, University of the Western Cape, South Africa.

Popoola, S.O. (2006). Personal factors affecting organizational commitment of records management personnel in Nigerian State Universities. Ife Psychologia, 14(1), 183-197. 
Popoola, S.O. (2007). Workplace, biographical and motivational factors affecting organizational commitment of records officers in Nigerian federal universities. African Journal of Library, Archives and Information Science, 17(1), 33-44.

Popoola, S.O. (2009). Organizational Commitment of Records Management Personnel in Nigerian Private Universities. Records Management Journal, 19(3), 204-217.

Porter, L.W., Steers, R.M., Mowday, R.T., \& Boulian, P.V. (1974). Organizational commitment, job satisfaction and turnover among psychiatric technicians. Journal of Applied Psychology, 59(5), 603-609.

Pratt, J. (2001). Changing patterns of diversity in Europe. Lessons from an OECD study tour. Higher Education Management, 13(2), 93-105.

Quirin, J.J., Donnelly, D.P., \& O'Bryan, D. (2001). Antecedents of organizational commitment: The role of perception of equity. Advances in Accounting Behavioural Research, 4, 261280.

Rahman, A. \& Hanafiah, H. (2002). Commitment to Organization versus Commitment to Profession: Conflict or Compatibility? Jurnal Pengurusan, 2, 77-94.

Rama-Krishna (n.d.). Psychological Empowerment and Organizational Commitment: An Empirical Study of Software Programmers in India. Retrieved from: http://www.scribd.com/doc/903744/Psychological-Empowerment-and-CommitmentRama-Krishna

Ramiall, S. (2004). A Review of Employee Motivation Theories and their Implications for Employee Retention within Organizations. Journal of the American Academy of Business, 5(1-2), 52-63.

Razali, M. Z., \& Vrontis, D. (2010). The reactions of employees toward the implementation of human resources information systems (HRIS) as a planned change program: A case study in Malaysia. Journal of Transnational Management, 15(3), 229-245.

Richards, B., O’Brien, T., \& Akroyd, D. (1994). Predicting the organizational commitment of marketing education and health occupations education teachers by work related rewards. Journal of Industrial Teacher Education, 32(1), 49-64.

Riketta, M. (2002). Attitudinal organizational commitment and job performance: A metaanalysis. Journal of Organizational Behavior, 23, 257-266.

Robertson Cooper \& Bank Workers Charity (2017). Making flexible working work: Moving from work-life balance to integration. Good Day at Work report. Retrieved from: https://www.robertsoncooper.com/work-life-integration

Rosdi, I.S. \& Harris, H. (2011). Human resource management practices and organizational commitment: The case of academics in a Malaysian higher education institution. Proceedings of International Conference on Business and Economic Research, Kedah, Malaysia, 1155-1173.

Rowley, D.J. \& Sherman, H. (2001). From strategy to change: Implementing the plan in higher education. San Francisco, CA: Jossey-Bass.

Sahinidis, A.G. \& Bouris, J. (2008). Employee perceived training effectiveness relationship to employee attitudes. Journal of European Industrial Training, 32(1), 63.

Salami, O.S. (2008). Demographic and psychological factors predicting organizational commitment among industrial workers. Anthropologist, 10(1), 31-38.

Schein, E.H. (1970). Organizational Psychology (2nd ed.). Englewood Cliffs, NJ: Prentice-Hall. Shahnawaz, M.G. \& Juyal, R.C. (2006). Human Resource Management Practices and Organizational Commitment in Different Organizations. Journal of the Indian Academy of Applied Psychology, 32(3), 171-178. 
Sharma, R.D. \& Jyothi, J. (2006). Job satisfaction among school teachers. IIMB Management Review, 18(4), 349-361.

Simosi, M. (2010). The role of social socialization tactics in the relationship between socialization content and newcomers' affective commitment. Journal of Managerial Psychology, 25(3), 301.

Simosi, M. \& Xenikou, A. (2010). The role of organizational culture in the relationship between leadership and organizational commitment: An empirical study in a Greek organization. International Journal of Human Resource Management, 21(10), 1598.

Smeenk, S.G.A., Eisinga, R.N., Teelken, J.C., \& Doorewaard, J.A.C.M. (2006). The effects of HRM practices and antecedents on organizational commitment among university employees. International Journal of Human Resource Management, 17(12), 2035-2054.

Srimannarayana, M. (2010, July). Human resource roles in India. Indian Journal of Industrial Relations, 46(1). Retrieved from: http://www.freepatentsonline.com/article/IndianJournal-Industrial-Relations/235631663.html

Stathakopoulos, V. (1996). Sales force control: A synthesis of three theories. Journal of Personal Selling \& Sales Management, 16(2), 1.

Steers, R.M. (1975). Problems in the measurement of organizational effectiveness. Administrative Science Quarterly, 20(4), 546-558.

Steers, R.M. (1977). Antecedents and outcomes of organizational commitment. Administrative Science Quarterly, 22, 46-56.

Steijn, B. \& Leisin, P. (2006) Organizational commitment among Dutch public sector employees. International Review of Administrative Sciences, 72(2), 187-201.

Stephens, R.D., Dawley, D.D., \& Stephens, D.B. (2004). Commitment on the Board: A Model of Volunteer Directors' Levels of Organizational Commitment and Self-reported Performance. Journal of Managerial Issues, 16(4), 583-504.

Steyn, G.M. (2002). A theoretical analysis of educator motivation and morale. Department of Further Teacher Education, Unisa, South Africa.

Stiles, D. (2004). Narcissus Revisited: The Values of Management Academics and their Role in Business School Strategies in the UK and Canada. British Journal of Management, 15(2), $157-175$.

Swist, T., \& Kuswara, A. (2016). Place-making in higher education: co-creating engagement and knowledge practices in the networked age. Higher education research \& development, 35(1), $100-114$

Tabbodi, M.L. \& Prahallada, N.N. (2009). The effects of leadership behavior on efficacy: A comparative study of faculty of two universities from Iran and India. Journal of Social Science, 20(3), 169-173.

Tasopoulou, K., Tasopoulou, K., Tsiotras, G., \& Tsiotras, G. (2017). Benchmarking towards excellence in higher education. Benchmarking: An International Journal, 24(3), 617-634.

Taiwo, K.O. (2003). An impact of locus of control on organizational commitment of female employees. Journal of Psychology, 2(1), 20-36.

Tella, A., Ayeni, C.O., \& Popoola, S.O. (2007). Work motivation, job satisfaction, and organizational commitment of library personnel in academic and research libraries in Oyo State, Nigeria. Library Philosophy and Practice, April, 1-16.

Theodosiou, M. \& Katsikea, E. (2007). An empirical investigation of the antecedents and consequences of export sales manager organizational commitment. AMA Winter Educators' Conference Proceedings, 18, 249. 
Tomprou, M., Nikolaou, I., \& Vakola, M. (2012). Experiencing organizational change in Greece: The framework of psychological contract. International Journal of Human Resource Management, 23(2), 385.

UGC Annual Report. (various years). New Delhi: University Grants Commission.

Unum. (2013) Bringing trust and motivation into the workplace. Retrieved from: http://online.positiveimagesuk.com/unum/images/UP3020.pdf

Vakola, M. \& Bouradas, D. (2005). Antecedents and consequences of organizational silence: An empirical investigation. Employee Relations, 27(5), 441-458.

Vakola, M. \& Nikolaou, I. (2005). Attitudes towards organizational change: What is the role of employees' stress and commitment? Employee Relations, 27(2), 160.

van Vught, F. (2008). Mission Diversity and Reputation in Higher Education. Higher Education Policy, 21, 151-174.

Vrontis, D., \& Thrassou, A. (2007). Adaptation vs. standardization in international marketingthe country-of-origin effect. Innovative marketing, 3(4), 7-20.

Weng, Q.X., McElroy, J.C., Morrow, P.C., \& Liu, R. (2010). The relationship between career growth and organizational commitment. Journal of Vocational Behavior, 77(3), 391-400.

Wissema, J.G. (2008). Towards the Third Generation University: Managing the University in Transition. Cheltenham, UK: Edward Elgar.

Yahaya, R., \& Ebrahim, F. (2016). Leadership styles and organizational commitment: Literature review. Journal of Management Development, 35(2), 190-216. https://doi.org/10.1108/JMD-01-2015-0004

Yousef, D.A. (1998). Satisfaction with job security as a predictor of organizational commitment and job performance in a multicultural environment. International Journal of Manpower, 19(3), 184-194.

Yousef, D.A. (2000). Organizational Commitment: A mediator of the relationship behaviour with job satisfaction and performance in a non western country. Journal of Managerial Psychology, 15(1), 6-24. 